\title{
Pattern of Self-Medication with Prescription Medicines Among Residents of Ilorin in North Central Nigeria
}

\author{
Jamiu Muslim Olakunle*, AbdulAzeez lyabode Fatima, Aliyu Fullaila Onozare
}

Department of Clinical Pharmacy and Pharmacy Practice, University of Ilorin, Ilorin, Nigeria

Authors' Contributions

1 Conception \& Study Design, Data Collection,

Data Analysis, Drafting.

2 Data Collection, Drafting.

3 Data Analysis, Critical Review.

\section{Article info.}

Received: December 19, 2019

Accepted: January 26, 2020

Funding Source: Nil

Conflict of Interest: Nil

Cite this article: Olakunle JM, Fatima Al, Aliyu FO. Pattern of Self-Medication with Prescription Medicines Among Residents of Ilorin in North Central Nigeria. RADS J Pharm Pharm Sci. 2019; 7(4): 191-198.

*Address of Correspondence Author: jamolakunle@gmail.com

\section{ABSTRACT}

Background: The challenge posed by inappropriate use of medicine is of global concern. It is associated with patient using his discretion to choose the type of medication to self-treat a perceived ailment and the choice of medication usually devoid of health care professional input.

Objective: The significance of this study was to assess the pattern of selfmedication with selected prescription medicines among residents of AgboOba area of Ilorin, Kwara State.

Method: The method was a descriptive cross-sectional study of residents of Agbo Oba area of Ilorin between January to May 2019 with self-designed validated questionnaire. Convenient sampling method was used to select the participant who met the criteria for selection.

Results: The mean age of the respondents was $38.5 \pm 11.8$ with minimum age of 19 and maximum age of 70 years. The most occurring age group was 26 35 years and primary school level of education, and artisan/trader were the most predominant in self-medication. Among the prescription medicines, antibiotics were the most self-used followed by steroids and cyproheptadine. Females were shown to practice self-medication more than their male counterpart. Marital status and level of education were factors that influenced awareness of risk factors associated with self-medication among the study participants, $p$-value $=0.017$ and 0.039 , respectively.

Conclusion: The prevalence of self-medication with prescription medicines was high and appeared to be more among female than male. Specifically, female misuse oral corticosteroids and cyproheptadine more and marital status and occupation type are strong predictors of their awareness of potential risks associated with self-use of prescription medicines.

Keywords: Prescription medicines, self-diagnosis, prevalence, llorin.

\section{INTRODUCTION}

Self-medication is the use of medicine by individuals to treat self-recognized illnesses or symptoms [1]. Medicines are usually selected by intending users for symptoms of perceived ailments in which the assessment was based on how the patient feel but not based on recommendation from a prescriber [2].
Essentially, the practice of self-medication with various classes of medication whether over-thecounter or prescription medicines is a worldwide problem. The practice is more predominant in underdeveloped or developed nations where access to health care may be poor or inability of the patient to afford a prescribed medication for a particular ailment and this however lead to inappropriate treatments of the patient condition [2]. 
The most widely used prescription medicine in selfmedication is antibiotic despite being prescription only medicines. This could be as a result of antibiotics could be from leftover medicines an individual has been previously recommended an antibiotic but did not finish the course of therapy. A friend or relative might have access to this and use with recommendation by a health care practitioner or purchase from a pharmacy or other medicine outlet in self capacity [3].

Incorrect self-diagnosis, refusal or delays in seeking necessary consultation and possible exposure to avoidable adverse effects from medicines and wrong method of administration are potential risks associate with self-use of medicines [4].

There could also be cases of disease masking, drug dependence and wrong choice of medicines among the users [4].

Peoples' lack of knowledge of antibiotic use could be an important reason for self-medication leading to inappropriate use [5].

Symptoms of some diseases that are perceived to be infectious in origin for instance, as rhinosinusitis, sore throats, bronchitis or earaches, cold and flu can be alleviated with over-the-counter medicines and in most cases, the immune system is able to deal with such mild infections [6-8].

Cyproheptadine is an antihistamine with additional and serotonergic activities. It also has a local anaesthetic effect. It's ability to improve sleep, calmness has been established. It also has negative symptoms in chronic schizophrenics who do not respond to other therapies. It's common adverse effects include drowsiness, dizziness, nausea, blurred vision, dry mouth, constipation, excitability, nervousness and restlessness [9].

Glucocorticoid dexamethasone is steroid drugs with anti-inflammatory and immunosuppressing activities. It is used to treat rheumatoid arthritis and bronchospasm. It has been clinically used in idiopathic thrombocytopenic purpura and adrenal insufficiency and Addison's disease [9].

It has been found that several African societies do not recognize obesity as a health problem, but as a display of social well-being and beauty especially among women and as such making it difficult for health care professional to achieve good weight control when needed [10].
On routine daily use, Cyproheptadine may cause several side effects, including drowsiness, tired feeling, insomnia, spinning sensation, blurred vision, and loss of coordination, upset stomach, and nausea, diarrhea, and weight gain [11].

Their ability to serve as mediators of the stress response, regulating both glucose homeostasis and the immune system explain its diverse use in many clinical important cases. It binds to specific receptor proteins in the target tissues to regulate the expression of corticosteroid responsive genes, changing the levels and arrays of proteins synthesized by the various target tissues [12, 13].

Steroid receptors are present in the brain, and interfere with various neurotransmission, including serotonin and dopamine. The direct effect of corticosteroids has been recognized which include effects on mood, behavior and brain excitability although the mechanisms whereby corticosteroids affect neuronal activity are unknown, but it has been proposed that steroids produced locally in the brain (neurosteroids) may regulate neuronal excitability [14].

Dexamethasone has been known to decrease body weight, rather than causes weight gain which at variance with general assumption, and whitening skin. There is also appearance of moon face resulting from the use of this drug and this occurs at initial use of the drug which is usually misconceived as weight gain [15].

Whitening of the skin observed is as a result from prevention of melanin synthesis which is essential for the protection of skin from ultraviolet light in which it increases susceptibility of skin cancer. It also antagonizes production which could predispose the patient to diabetic mellitus or impaired glucose control in diabetic patient, with aldosterone functions [15].

The role of pharmacists in optimizing therapeutic care for the patient include implementation of strict regulatory mechanisms to restrict over the counter dispensing of prescription medicines [15]. Selftreatment with antibiotics has been shown to be prevalent in respiratory conditions and co-trimoxazole and amoxicillin were the two most common antibiotics involved [16].

Studies on pattern and prevalence are available in some parts of the world like India [17], Democratic Republic of Congo [10], Sudan [2]. 
In Nigeria, most findings were on general concept of self-medication without being specific except few on antibiotics [18].

In view of this, there is need to investigate the trend of use of some commonly used prescription medicine among the residents of llorin.

\section{MATERIALS AND METHODS}

The study was conducted among residents of Agbooba area of Ilorin in Ilorin West Local Government Area of Kwara State from January to May 2019. Agbo-oba is located in the North Eastern part of Ilorin bounded in the South West by Adewole area, in the East by Surulere, in the North East by Kuntu/Adeta. The residents were predominantly low income earners with petty trading and student occupants of Kwara State College of Education, Institute of Technology of Kwara State Polytechnic and AlHikmah University and in this study we employed a descriptive cross-sectional design, and residents who were 18 years and above were included in the study. A sample size of 294 was calculated using Fisher's formula for a study using analytical study design with the level of confidence set at $95 \%$ and a precision of 0.05 [19].

Ten percent (10\%) attrition rate was used to cater for nonresponse or rejection of improperly filled questionnaires. Convenient sampling method was used for participants which was done randomly by selecting subject who patronize whether a Pharmacy, Patent Medicine Store or any other outlet where medicine could be obtained. Selection of subject included any resident that obtained a medication which involved items of interest in this study viz: selected oral antibiotics, Cyproheptadine, Dexamethasone tablet, male sexual enhancers and salbutamol tablet in any outlet for sales and dispensing of medicines. The choice of this line of medication was borne out of long time observation of over the counter use of these drugs. In the study area, there are about five registered pharmacies viz: Adewole Pharmacy, Al-Mufid Pharmacy, Island Pharmacy and Tunmise Pharmacy while there were over forty patent medicine stores spread across the streets of the community.

The questionnaire used was assessed for face and content validity by all the researchers in the study. Cronbach alpha of 0.73 was obtained when the reliability of the questionnaire was assessed and literatures related to the study objectives were searched to enhance the quality of the questionnaire. The questionnaire was divided into two parts.

The first parts contained patient demographic information while the second part contained question items used to elicit information on self-medication with selected prescription medications like oral corticosteroids, bronchodilators, antibiotics and so on. The semi-structured questionnaire was pretested at Sawmill area of llorin where about 35 participants were used for the pretesting. Where necessary, the corrections were made on the questionnaires was self- administered by the respondents.

Interviewer administer method was used and respondent who could not speak the official English language were spoken to in the local language of Yoruba.

The purpose of the study was explained to the respondents and their verbal consent to participate in the study were sought and obtained before the questionnaires were administered. Data were analyzed using Statistical Package for Social Sciences (SPSS) version 20. Data were presented in frequency tables with percentages, means, and standard deviation. Bivariate analysis was done using chi-squared and logistic regression analysis. P-value less than $<0.05$ was considered to be significant.

\section{Ethical Approval}

The study was approved by the Ministry of Health, llorin, Kwara State. Informed consent of the participants was obtained and the participation was voluntary without any form of financial inducement or coercion.

\section{RESULTS}

Out of 294 questionnaires processed for interview, 283 were returned and suitable for use giving a response rate of $96.3 \%$. The mean age of the respondents was $38.5 \pm 11.8$ with minimum age of 19 and maximum age of 70 years (Table 1 ).

On the awareness of the respondents on whether they were aware of the prescribing status of the medications they were taking or not, only $30.7 \%$ $(n=87)$ were aware they should receive prescription from a qualified medical practitioner before taking the medications (Table 2). 
Assessing the relationship between demographic variables and awareness of risk of self-medication with prescription medication provide these results (Table 3).
The association between the awareness of risk associated with use of prescription medication and willingness of the respondents to stop the practice using logistic regression analysis showed that chi square was 0.379 and a $p$-value of 0.538 .

Table 1. Demographic characteristics of the respondents.

\begin{tabular}{|c|c|c|c|}
\hline Variable & Values & Number & Percentage \\
\hline \multirow{4}{*}{ Age } & $\leq 25$ & 31 & 10.9 \\
& $26-35$ & 123 & 43.5 \\
& $36-45$ & 57 & 20.1 \\
& $46-55$ & 44 & 15.6 \\
& $\geq 56$ & 28 & 9.9 \\
\hline \multirow{2}{*}{ Gender } & Male & 108 & 38.2 \\
& Female & 175 & 61.8 \\
\hline \multirow{3}{*}{ Marital Status } & Single & 59 & 20.8 \\
& Married & 191 & 67.5 \\
& Divorced/Widowed & 33 & 11.7 \\
\hline \multirow{3}{*}{ Level of Education } & Non Formal & 52 & 18.4 \\
& Primary & 119 & 42.0 \\
& Secondary & 77 & 27.2 \\
& Tertiary & 35 & 12.4 \\
\hline \multirow{3}{*}{ Occupation } & Unemployed & 44 & 15.5 \\
& Student & 79 & 28.0 \\
& Artisan/Trader & 102 & 36.0 \\
& Civil Servant & 52 & 18.4 \\
& Retiree & 6 & 2.1 \\
\hline
\end{tabular}

Table 2. Frequency distribution of the medications taken by the respondents.

\begin{tabular}{|c|c|c|}
\hline Medicine Class & Medicine Name & $\mathbf{N}(\%)$ \\
\hline \multirow{4}{*}{ Antibiotics } & Ampiclox & $141(49.8)$ \\
\cline { 2 - 3 } & Ampicillin & $119(42.1)$ \\
\cline { 2 - 3 } & Amoxicillin & $68(24.0)$ \\
\cline { 2 - 3 } & Chloramphenicol & $79(27.9)$ \\
\cline { 2 - 3 } & Greseofulvin (Fulcin) & $23(8.1)$ \\
\cline { 2 - 3 } & Co-trimoxazole & $105(37.1)$ \\
\hline \multirow{2}{*}{ Corticosteroids } & Dexamethasone & $167(59)$ \\
\hline Antihistamine & Prednisolone & $63(22.3)$ \\
\hline \multirow{2}{*}{ Bronchodilator } & Cyproheptadine & $178(62.9)$ \\
\hline \multirow{2}{*}{ Aphrodisiac } & Salbutamol & $94(33.2)$ \\
\cline { 2 - 3 } & Aminophyllin & $20(7.1)$ \\
\hline \multirow{2}{*}{ Sources where medicines were mostly obtained } & Sidenafil & $67(62.0)^{*}$ \\
\cline { 2 - 3 } & Tadalafil & $133(41.7)^{*}$ \\
\cline { 2 - 3 } & Pharmacy & $97(34.3)$ \\
\cline { 2 - 3 } & Medicine store & \\
\cline { 2 - 3 } & & $53(18.7)$ \\
\hline
\end{tabular}




\begin{tabular}{|c|c|c|}
\hline \multirow{4}{*}{ Reasons for taking the medication(s) } & Infection & $187(66.1)$ \\
\cline { 2 - 3 } & Cough & $94(33.2)$ \\
\cline { 2 - 3 } & (Aphrodisiac) Man power & $67(62.0)^{*}$ \\
\cline { 2 - 3 } & Weight gain & $167(59.0)$ \\
\cline { 2 - 3 } & No reasons & $9(3.2)$ \\
\cline { 2 - 3 } mo you seek counseling when obtaining your & Sleep & $66(23.3)$ \\
\cline { 2 - 3 } medications? & Yes & $122(43.1)$ \\
\hline \multirow{2}{*}{ How long have you been taking the } & No & $161(56.9)$ \\
\hline medications(s)? & Few months (less than 1 year) & $39(13.8)$ \\
\cline { 2 - 3 } & Few years (1-10 years) & $119(42.1)$ \\
\cline { 2 - 3 } & More than 10 years & $133(47.0)$ \\
\hline \multirow{3}{*}{$\begin{array}{c}\text { Are you aware of the possible risk associated with } \\
\text { prolonged use of these medicines? }\end{array}$} & Yes & $105(37.1)$ \\
\cline { 2 - 3 } self-mat extent did you perceive the danger of & No & $178(62.9)$ \\
\cline { 2 - 3 } & High & $54(19.1)$ \\
\cline { 2 - 3 } & Moderate & $55(19.4)$ \\
\cline { 2 - 3 } & Low & $56(19.8)$ \\
\hline Are you willing to stop taking the medicines except & None & $118(41.7)$ \\
\cline { 2 - 3 } on medical recommendation? & Yes & $155(54.8)$ \\
\cline { 2 - 3 } & No & $128(45.2)$ \\
\hline
\end{tabular}

${ }^{*}$ Out of a total number of 108 male respondents

Table 3. Association between socio-demographic variables and awareness of risk of self-medication with prescription medicines.

\begin{tabular}{|c|c|c|c|c|c|}
\hline \multicolumn{2}{|c|}{ Variable } & \multicolumn{2}{|c|}{$\begin{array}{c}\text { Awareness of risk associated with self- } \\
\text { medication with prescription } \\
\text { medicines }\end{array}$} & \multirow[t]{2}{*}{$\mathrm{X}^{2}$} & \multirow[t]{2}{*}{ P-Value } \\
\hline & & Yes $(n=105)$ & No $(n=178)$ & & \\
\hline Gender & $\begin{array}{c}\text { Male } \\
\text { Female }\end{array}$ & $\begin{array}{l}44(41.9) \\
61(58.1) \\
\end{array}$ & $\begin{array}{c}64(36.0) \\
114(64.0) \\
\end{array}$ & 1.25 & 0.310 \\
\hline Age (years) & $\begin{array}{c}\leq 25 \\
26-35 \\
36-45 \\
46-55 \\
\geq 56\end{array}$ & $\begin{array}{c}13(12.4) \\
44(41.9) \\
21(20.0) \\
17(16.2) \\
10(9.5)\end{array}$ & $\begin{array}{l}18(10.1) \\
79(44.4) \\
36(20.2) \\
27(15.2) \\
18(10.1)\end{array}$ & 0.473 & 0.976 \\
\hline $\begin{array}{l}\text { Educational } \\
\text { Qualification }\end{array}$ & $\begin{array}{l}\text { Non Formal } \\
\text { Primary } \\
\text { Secondary } \\
\text { Tertiary }\end{array}$ & $\begin{array}{c}21(20) \\
44(41.9) \\
29(27.6) \\
11(10.5)\end{array}$ & $\begin{array}{l}31(17.4) \\
75(42.1) \\
48(47.5) \\
24(13.5)\end{array}$ & 0.734 & 0.865 \\
\hline Marital Status & $\begin{array}{c}\text { Single } \\
\text { Married } \\
\text { Divorced/ } \\
\text { Widowed }\end{array}$ & $\begin{array}{l}13(12.4) \\
76(72.4) \\
16(15.2)\end{array}$ & $\begin{array}{c}46(25.8) \\
115(64.6) \\
17(9.6)\end{array}$ & 8.16 & $0.017^{*}$ \\
\hline $\begin{array}{l}\text { Occupational } \\
\text { Status }\end{array}$ & $\begin{array}{l}\text { Unemployed } \\
\text { Student } \\
\text { Artisan/Trader } \\
\text { Civil Servant } \\
\text { Retiree }\end{array}$ & $\begin{array}{c}16(15.2) \\
24(22.9) \\
34(32.4) \\
27(25.7) \\
4(3.8)\end{array}$ & $\begin{array}{c}28(15.7) \\
55(30.9) \\
68(38.2) \\
25(14.1) \\
2(1.1)\end{array}$ & 9.303 & $0.039^{*}$ \\
\hline
\end{tabular}

${ }^{*} X^{2}$ with $P<0.05$ is statistically significant 


\section{DISCUSSION}

The survey enjoyed a high response rate from the target participants which was an indication for willingness of the participants voluntary participation in the study.

Majority of the respondents had primary school qualification as their highest level of education while only a few of them had tertiary level of education (Table 1). This could be the reason why occupational distribution of the respondents showed a higher proportion of artisans or traders above others.

Ampiclox, cyproheptadine and dexamethasone were found to be the most commonly used prescription medicines among the residents. This finding was similar to a study carried out in Kinshasa, DRC in 2016 where the prevalence of misuse of cyproheptadine was found to be $72.9 \%$. The percentage average of antibiotics used was $30.4 \%$ which is higher than the result obtained from a study carried out in Pakistan by Nazir and Azim (2014) where a prevalence rate of $26 \%$ was obtained [20].

Antibiotic resistance has been attributed to the prevalence of antibiotic resistance which has the left clinicians with limited drug options for the treatment of bacterial infectious diseases [21].

Although majority of the respondents claimed to use the antibiotics for infection purpose there was no important mentioning of particular infection which the antibiotics were used for except in few cases of ring worm and rashes.

The use of salbutamol for management of asthma was unsubstantiated as there was no proof of diagnosis of obstructive respiratory condition except that they feel or had information that salbutamol could be used to manage cough. However, salbutamol has not been found to be useful in non- obstructive airway disease cough [22].

The most important reason why respondents took cyproheptadine and dexamethasone was weight gain. Most of the users were not aware of the risk associated with the use. Although the users might be interested in achieving this after a long period of use but this effect is short lived as reported by Karia et al. (2013) [23]. Most users of dexamethasone and cyproheptadine either alone or in combinations for weight gain could not hide the purpose of use as they see weight gain as a reflection of a good nutritional wellbeing and did not see it as having any negative impact on their health.

A higher percentage (62.9\%) of respondents was unaware of the risk associated with unauthorized use of prescription medicines. This could be as a result of medicines outlet not engaging in educating the recipients or their resistance to being educated about their medications. This was reflected in the study as higher number of respondents did not seek to be counseled about their medications but were willing to quit the act if they are convinced about the risk associated with their attitude. There is possibility that there was no voluntary patient education and counseling in most of the drug outlets in the study area. About half of the respondents (47\%) obtained their medicines strictly from pharmacies. Documented evidence showed that pharmacists provide patient counseling and education in their premises [24] although some deficiencies affecting quality of counseling to the patient that hinders the quality of service and its beneficial effect to the patients have been identified [24, 25]. Moreover, substantial number of respondents (34.3\%) sourced their medicines from proprietary medicine stores who are in the first place were not authorized to stock prescription medicines [26] where possibility of adequate knowledge to provide patient education and counseling may be unrealistic because of limited knowledge the practitioners have in drug therapy [27]. This could possibly the reason while most respondents were deficient in knowledge of prescribing status of the medicines, awareness and extent of risk associated with the medications they use.

Marital status and occupation of the respondents play a significant role in their awareness of risk associated with self-medication with prescription medicines ( $p$ values 0.017 and 0.039 , respectively). Younger adults tend to use more drugs than the older ones especially those within the age of 26-35 years and more of female than male. This could result from young female ones trying to use medicine that could enhance their appearances though body size increase and weight gain by using appetite stimulants like cyproheptadine and dexamethasone.

The influence of occupation of the respondents on their awareness of risk associated with selfmedication with prescription medicines could be as a result of influence of educational level on knowledge of medication use. There were reasonable numbers of respondents who were artisan/trader and were with 
low level of education. Consequently, there awareness of risk could be significantly low as confirmed by this study. A similar study conducted in Lagos, Nigeria also found association between occupation and self-medication to be significant [16]. Although, respondents level of education had no influence on the choice of sourcing for their medicines and awareness of risk associated with self-medication with prescription medicines. This is contrary to a study carried out in Lagos where level of education was found to be a strong predictor of self -medication [27]. Knowledge of prescribing status of the medications influenced willingness to quit selfmedication practice among but not their awareness of risks associated with the medicine. One would expect that the awareness of risk would prompt the respondents to quit the practice but this was not case. This could be as a result of their poor knowledge of extent of the risks associated and with specific knowledge of those risks, of poor interaction between the residents and the owners of outlets for medicine sources. The high numbers of patient medicine vendors compared to pharmacy outlets which could debar the residents from qualitative medication counseling.

Being a student or civil servant was an independent factor for the awareness of risk associated with use of one or more of prescription medicines. This could be as a result of increased level of education and exposure among these groups of respondents. This result is consistent with a study carried out among Ras AI-Khaimah population in UAE where occupation had significant relationship with knowledge and awareness of consequences associated with selfmedication practices [1].

\section{CONCLUSION}

There was high prevalence of self-medication with prescription medication among the study population which was more common among female population. There was significant relationship between respondents' knowledge of prescribing status of the medicines and their willingness to stop the practice of self-medication. Their awareness of risks associated with self-medication with prescription drug was significantly associated with marital and occupational status of the study population.

\section{ACKNOWLEDGEMENTS}

Participants and research assistants who are staff of Al-Mufihd Pharmacy, Agbo-oba area are really appreciated.

\section{REFERENCES}

1. Sridhar SB, Shariff A, Dallah L, Anas D, Ayman M, Rao PGM. Assessment of Nature, Reasons, and Consequences of Self-medication Practice among General Population of Ras Al-Khaimah, UAE. Int J Appl Basic Med Res. 2018; 8(1):3-8.

2. Awad A, Eltayeb I, Matowe L, Thalib L. Selfmedication with Antibiotics and Antimalarials in the community of Khartoum State. Sudan J Pharm Pharm Sci. 2015; 8(2):326-31.

3. Heikkinen $T$, Järvinen $A$. The common cold. Lancet. 2003; 361(9351):51-9.

4. Ruiz ME. Risks of Self-Medication Practices. Curr Drug Safety. 2010; 5(4): 315-23.

5. Elong Ekambi GA, Okalla Ebongue C, Penda IC, Nnanga Nga E, Mpondo Mpondo E, Eboumbou Moukoko CE. Knowledge, practices and attitudes on antibiotics use in Cameroon: Self-medication and prescription survey among children, adolescents and adults in private pharmacies. PLoS One. 2019; 14(2):e0212875.

6. Spinks A, Glasziou P, Del Mar CB. Antibiotics for sore throat. Cochrane Database Syst Rev. 2013; (11):CD000023.

7. van Vugt SF, Butler CC, Hood K, Kelly MJ, Coenen S, Goossens $\mathrm{H}$, et al. Predicting benign course and prolonged illness in lower respiratory tract infections: a 13 European country study. Fam Pract 2012; 29(2):131-8.

8. Young J, De Sutter A, Merenstein D. Antibiotics for adults with clinically diagnosed acute rhinosinusitis: a meta-analysis of individual patient data. Lancet. 2008; 371(9616):908-14.

9. Karia S, Dave N, De Sousa A, Shah N, Sonavane S. Cyproheptadine and dexamethasone abuse. Nat J Med Res. 2013; 3(1):88-9.

10. Lulebo AM, Bavuidibo CD, Mafuta EM, Ndelo JD, Mputu LM, Kabundji DM, et al. The misuse of Cyproheptadine: a non-communicable disease risk behavior in Kinshasa population, Democratic Republic of Congo. Subst Abuse Treat Prev Policy. 2016; 11:7.

11. Nilsson S, Allebeck $P$, Marklund B, Baigi A, Fridlund B. Evaluation of a health promotion programme to prevent misuse of androgenic anabolic steroids among Swedish adolescents. Health Promot Int. 2004; 19(1):61-7.

12. Armstrong EJ, Dluhg RG. Pharmacology of the adrenal cortex. In: Golan DE, editor. Principles of Pharmacology. 2nd ed. New Delhi: Wolters Kluwer; 2008; 498-502. 
13. Stahn C, Buttgereit F. Genomic and nongenomic effects of glucocorticoids. Nat Clin Pract Rheumatol. 2008; 4(10):525-33.

14. Mahar S, Malhotra M. Dexamethasone-induced withdrawal seizure. J Pharmacol Pharmacother. 2015; 6(2):103-4.

15. Amar MI, Adam Shama IY, Enaia AA, Hind AEO, Hager AM. Effects of Various Levels of Oral Doses Dexamethasone (Al-nagma) Abused as Cosmetic by Sudanese Women on Wistar Rats. J Med Sci. 2013; 13(6):432-8.

16. Ngu RC, Feteh VF, Kika BT, Nerice FEK, Ayeah $\mathrm{CM}$, Chifor T, et al. Prevalence and Determinants of Antibiotic Self-Medication among Adult Patients with Respiratory Tract Infections in the Mboppi Baptist Hospital, Douala, Cameroon: A CrossSectional Study. Diseases. 2018; 6(2). pii: E49.

17. Barker AK, Brown K, Ahsan M, Sengupta S, Safdar $\mathrm{N}$. Social determinants of antibiotic misuse: a qualitative study of community members in Haryana, India. BMC Public Health. 2017; 17(1):333.

18. Aday LA, Cornelius LJ. Designing and Conducting Health Surveys: A Comprehensive Guide, JosseyBass, San Francisco, CA, USA, 3rd edition; 2006.

19. Nazir S, Azim M. Assessment of antibiotic selfmedication practice among public in the northwestern region of Pakistan. Eur $\mathrm{J}$ Hospital Pharm. 2017; 24(4):200-3.

20. Sapkota AR, Coker ME, Rosenberg Goldstein RE, Atkinson NL, Sweet SJ, Sopeju PO, et al. Selfmedication with antibiotics for the treatment of menstrual symptoms in Southwest Nigeria: a cross-sectional study. BMC Public Health. 2010; 10:610.

21. Molassiotis A, Smith JA, Bennett MI, Blackhall F, Taylor D, Zavery B, et al. Clinical expert guidelines for the management of cough in lung cancer: report of a UK task group on cough, Cough. 2010; 6:9.

22. Eades CE, Ferguson JS, O'Carroll RE. Public health in community pharmacy: A systematic review of pharmacist and consumer views. BMC Public Health. 2011; 11:582.

23. Surur AS, Getachew E, Teressa E, Hailemeskel B, Getaw NS, Erku DA. Self-reported and actual involvement of community pharmacists in patient counseling: a cross-sectional and simulated patient study in Gondar, Ethiopia. Pharm Pract (Granada). 2017; 15(1):890.

24. Beyeler N, Liu J, Sieverding M. A Systematic Review of the Role of Proprietary and Patent Medicine Vendors in Healthcare Provision in Nigeria. PLoS One. 2015; 10(1):e0117165.

25. Okonkwo AD, Okonkwo UP. Patent medicine vendors, community pharmacists and STI management in Abuja, Nigeria. Afr Health Sci. 2010; 10(3):253-65.

26. Afolabi AO. Factors influencing the pattern of selfmedication in an adult Nigerian population. Ann Afr Med. 2008; 7(3):120-7.

27. Ayanwale MB, Okafor IP, Odukoya OO. Selfmedication among rural residents in Lagos, Nigeria. J Med Trop. 2017; 19(1):65-71. 